\title{
Sprawozdanie z Krajowego Zjazdu Delegatów Polskiego Towarzystwa Dermatologicznego
}

\author{
Wrocław, 13.05.2016 r.
}

Przegl Dermatol 2016, 103, 258

13 maja 2016 r. w ramach 31. Zjazdu Polskiego Towarzystwa Dermatologicznego (PTD) odbył się Krajowy Zjazd Delegatów PTD. Doktor hab. med. Rafał Białynicki-Birula został wybrany przewodniczącym Zjazdu, natomiast funkcję sekretarza Krajowego Zjazdu Delegatów powierzono dr med. Joannie Salomon. W ramach posiedzenia Krajowego Zjazdu Delegatów PTD powołano następnie Komisję Skrutacyjną w składzie: dr med. Andrzej Jaworek (przewodniczący), dr med. Anna Baran, dr med. Magdalena Kiedrowicz oraz lek. Joanna Gruber.

Po wysłuchaniu sprawozdań z mijającej kadencji ustępującego prezesa PTD prof. dr. hab. med. Jacka Szepietowskiego oraz przewodniczącego Głównej Komisji Rewizyjnej (GKR) prof. dr. hab. med. Ryszarda Żaby Zgromadzenie Delegatów udzieliło absolutorium ustępującemu Zarządowi Głównemu PTD.

W dalszym etapie Zjazdu delegaci wysłuchali wystąpień kandydatek do objęcia funkcji prezesa PTD: prof. dr hab. med. Joanny Narbutt i prof. dr hab. med. Lidii Rudnickiej. Po tej części zebrania w głosowaniu tajnym delegaci wybrali nowego prezesa PTD, którym została prof. dr hab. med. Lidia Rudnicka. W trakcie Krajowego Zjazdu Delegatów wybrano także członków nowego Zarządu Głównego PTD w osobach:

1. prof. dr hab. med. Zygmunt Adamski

2. prof. dr hab. med. Ligia Brzezińska-Wcisło

3. prof. dr hab. med. Grażyna Chodorowska

4. dr hab. med. Rafał Czajkowski, prof. nadzw.

5. prof. dr hab. med. Magdalena Czarnecka-Operacz

6. dr med. Joanna Czuwara

7. prof. dr hab. med. Iwona Flisiak

8. dr med. Monika Kapińska-Mrowiecka

9. prof. dr hab. med. Andrzej Kaszuba

10. prof. dr hab. med. Cezary Kowalewski

11. prof. dr hab. med. Dorota Krasowska

12. dr hab. med. Aleksandra Lesiak

13. dr hab. med. Joanna Maj, prof. nadzw.

14. prof. dr hab. med. Sławomir Majewski

15. prof. dr hab. med. Romuald Maleszka

16. prof. dr hab. med. Joanna Narbutt

17. prof. dr hab. med. Roman Nowicki
18. dr hab. med. Witold Owczarek, prof. WIM

19. prof. dr hab. med. Waldemar Placek

20. dr hab. med. Adam Reich, prof. nadzw.

21. dr hab. med. Małgorzata Sokołowska-Wojdyło, prof. nadzw.

22. prof. dr hab. med. Jacek Szepietowski

23. prof. dr hab. med. Anna Wojas-Pelc

24. prof. dr hab. med. Anna Woźniacka

25. dr hab. med. Barbara Zegarska, prof. nadzw.

oraz dokonano wyboru przewodniczącego i członków Głównej Komisji Rewizyjnej:

1. dr hab. med. Anna Lis-Święty (przewodnicząca)

2. dr med. Ewa Chlebus

3. dr med. Agnieszka Owczarczyk-Saczonek

4. dr med. Grażyna Wąsik

5. prof. dr hab. med. Anna Zalewska-Janowska

Następnie, na wniosek prof. dr. hab. med. Jacka Szepietowskiego, delegaci zatwierdzili miejsce kolejnego zjazdu PTD, który odbędzie się w Lublinie, a funkcję przewodniczącego Komitetu Organizacyjnego powierzono prof. dr hab. med. Dorocie Krasowskiej. Nowo powołana prezes PTD prof. dr hab. med. Lidia Rudnicka złożyła podziękowania ustępującemu prezesowi oraz Zarządowi Głównemu za dotychczasową pracę oraz wystąpiła z wnioskiem o nadanie godności Honorowego Prezesa PTD prof. dr. hab. med. Jackowi Szepietowskiemu. Wniosek został zatwierdzony przez Zgromadzenie w głosowaniu tajnym.

W związku z brakiem innych komunikatów i wniosków przewodniczący ogłosił zakończenie zebrania.

Zgodnie ze Statutem PTD nowo wybrany Zarząd Główny PTD wybrał spośród swoich członków prezydium Zarządu Głównego PTD w składzie:

1. prof. dr hab. med. Waldemar Placek - wiceprezes

2. prof. dr hab. med. Anna Wojas-Pelc - wiceprezes

3. prof. dr hab. med. Zygmunt Adamski - skarbnik

4. dr hab. med. Adam Reich, prof. nadzw. - sekretarz

5. dr hab. med. Barbara Zegarska, prof. nadzw. - zastępca sekretarza

6. prof. dr hab. med. Ligia Brzezińska-Wcisło - członek Prezydium

7. prof. dr hab. med. Roman Nowicki - członek Prezydium

Joanna Salomon sekretarz Krajowego Zjazdu Delegatów Polskiego Towarzystwa Dermatologicznego Adam Reich sekretarz Polskiego Towarzystwa Dermatologicznego 